\title{
Non-melanoma Skin Cancers Reported at a Secondary Care Institution in Milas
}

\section{ikinci Basamak Sağlık Kuruluşu Non-melanom Deri Kanseri Verileri: Milas Yöresi}

\author{
Şenay Ağırgöl, Korkut Bozkurt* \\ University of Health Sciences, Haseki Training and Research Hospital, Clinic of Dermatology, Istanbul, Turkey \\ *Milas Government Hospital, Department of Pathology, Muğla, Turkey
}

\begin{abstract}
Aim: We investigated demographic features, tumor location and histopathology as well as frequency of recurrence of nonmelanoma skin cancer (NMSC) in patients in Milas region.

Methods: Medical files of 120 patients with the diagnosis of NMSC, who attended the dermatology department at Milas State Hospital between 2011 and 2014, were analyzed retrospectively. Statistical analysis was performed by evaluating demographic characteristics (age, gender, tumor initial age), alcohol consumption, smoking habits, occupation, Fitzpatrick skin type (FT), location of lesions, tumor histopathology and recurrence frequency.
\end{abstract}

Results: The average age at admission was 65.2 years. Male/female ratio was equal and the number of females with basal cell carcinoma (BCC) was higher than that of males, while squamous cell cancer was more common in men. $88.3 \%$ of the lesions involved the head and neck region. The most common location was the nose (19.7\%), followed by eye and ear region. 70.8\% of patients had FT 1 and 2 and $70 \%$ had light eye color. There were more than one lesion in five patients and recurrence was observed in 15 of the patients. The most common histopathologic type was nodular, followed by infiltrative and superficially spreading BCC. Almost all of our patients were active farmers.

Conclusion: During the three-year follow-up period, NMSCs were reported to have a high rate of frequency and recurrence. We believe that skin cancers constitute an important health problem for this town and this can grow unless necessary measures are taken.

Keywords: Non-melanoma skin cancer, Milas, basal cell carcinoma, squamous cell carcinoma
Öz

Amaç: Bu çalışmada Milas yöresinde görülen non-melanoma deri kanseri (NMDK) hastalarından devlet hastanesine başvuranların demografik özellikleri, tümör lokalizasyonu ve histopatolojisi ile tümörlerin rekürrens sıklığı çalışıldı.

Yöntemler: Çalısmada 2011-2014 yılları arasında; dermatoloji kliniğinde görülen 120 NMDK tanılı hastaların dosyaları retrospektif olarak incelendi. Hastaların demografik özellikleri, alkol ve sigara kullanımı, mesleği, Fitzpatrick deri tipi (FT), lezyonların lokalizasyonu, tümör histopatolojisi ile rekürrens sıklığı değerlendirilerek istatistiksel analiz yapıldı.

Bulgular: Hastaların başvuru sırasındaki yaş ortalaması 65,2 olarak bulundu. Erkek ve kadın oranı eşitti ve bazal hücreli karsinom (BHK) hastalarında kadın sayısı, skuamöz hücreli kanser hastalarında erkek sayısı fazla idi. Lezyonların \%88,3'ü baş-boyun bölgesinde görüldü. En yaygın lokalizasyon burun olup $(\% 19,7)$ bunu göz ve kulak çevresi izledi. Hastaların \%70,8'i FT 1 ve 2, \%70 hasta açık renk göze sahipti. Beş hastada birden fazla lezyon vardı ve hastaların 12 tanesinde rekürrens görüldü. En sık karşılaşılan histopatolojik tip nodüler olup bunu infiltratif ve yüzeyel yayılan BHK izledi. Hastalarımızın neredeyse hepsi tarım ile aktif uğraşan bireylerdi.

Sonuç: Üç yıllık takipte ilçenin ikinci basamak sağlık kuruluşunda tespit edilen olguların sıklığının ve rekürrensin yüksek olduğu tespit edilmiştir. Deri kanserleri sıklığının ve tedavisinin bu bölge için önemli bir sağlık problemi olduğunu ve koruyucu önlemler alınmazsa bunun artacağını düşünmekteyiz.

Anahtar Sözcükler: Non-melanom deri kanserleri, Milas, bazal hücreli karsinom, skuamoz hücreli karsinom
Address for Correspondence/Yazışma Adresi: Senay Ağırgöl

University of Health Sciences, Haseki Training and Research Hospital, Clinic of Dermatology, İstanbul, Turkey E-mail: senayagirgol@hotmail.com ORCID ID: orcid.org/0000-0002-8000-8883

Received/Geliş Tarihi: 19 August 2017 Accepted/Kabul Tarihi: 7 April 2017
${ }^{\circ}$ Copyright 2017 by The Medical Bulletin of University of Health Sciences Haseki Training and Research Hospital
The Medical Bulletin of Haseki published by Galenos Yayınevi.

๑Telif Hakkı 2017 Sağlık Bilimleri Üniversitesi Haseki Eğitim ve Araştırma Hastanesi Haseki Tıp Bülteni, Galenos Yayınevi tarafından basıımıştı. 


\section{Introduction}

Non-melanoma skin cancers (NMSCs) are among the most common malignancies seen worldwide and in our country (1). Although it has a low mortality, it can cause disfiguration because it is frequently located in the head and neck region and morbidity is rather high, causing economic loss (2-5). There is no sufficient information on the incidence of the disease in our country. Information about its incidence and characteristics are usually obtained from retrospective analysis of the patient archives (3).

NMSCs include the two most common types of cancers; basal cell carcinoma (BCC) originating from the basal layer of the epidermis and skin adnexa, and squamous cell carcinoma (SCC) developing from atypical epidermal keratinocytes. BCC is stable, slow-growing tumor with a very low risk of metastasis, while SCC has a more aggressive course, grows rapidly and has a high risk of metastasis. The major etiologic factor in the development of BCC and SCC is exposure to ultraviolet beams, particularly ultraviolet $B(2,5)$.

The Fitzpatrick skin type classification denotes six different skin types, skin color, and reaction to sun exposure which ranges from very fair (skin type I) to very dark (skin type $\mathrm{VI}$ ) depending upon whether the patient burns at the first average sun exposure or tans at the first average sun exposure (2).

\section{Methods}

Data of patients with NMSC diagnosis were screened in Milas State Hospital. Patients who had been followed up for at least six months were included in the study. Age, gender, skin type, smoking, alcohol use, tumor location and clinical data were evaluated according to the histopathologic types. Facial area was recorded as nose, zygoma, around ear, lower lip, chin, scalp, frontotemporal, orbital, nose and neck. Histopathology of the lesions was classified as BCC and SCC. BCC was evaluated as nodular, micronodular, morpheic, superficially spreading and infiltrative; whereas SCC was evaluated in subgroups of in situ, well, moderate and poorly differentiated, and not classified.

\section{Statistical Analysis}

The SPSS statistical package (Version 16.0, SPSS, Inc., Chicago, IL) was used for analysis.

Descriptive statistics of demographic and other variables were recorded. Student's t-test and the MannWhitney $U$ test for independent samples were used for all parametric and nonparametric analyses, respectively. The chi-square test was used for qualitative variables. In all statistical tests; a p value of less than 0.05 was considered statistically significant.

\section{Results}

Eighty four (70\%) of 120 patients who had been diagnosed with NMSC had BCC, and $36(30 \%)$ had SCC. The male/female ratio was equal. BCC patients consisted of 21 men and 15 women; SCC group included 39 men and 45 women. Skin type was FT 1 and 2 in 85 patients, 50 cases had dark eye color, and 70 had light eye color. Recurrence was observed in 15 patients (Table 1). Two of these cases had the third recurrence, while one had the fourth recurrence. The subject who had the forth recurrence was a homeless patient with multiple actinic keratosis and more than one lesion. SCC and BCC most commonly occurred in the seventh decade of life both in men and women.

There were no any skin cancer cases in the first decade of life. Most patients were in the age group of 60-70 years. Although there were cases with tumor involvement of the body regions such as lumbosacral, abdominal and lower extremities, tumor spread was mostly observed in the head and neck region (88.3\%) in cases with BCC (Table 2).

Lesions were found mostly on the nose, followed by central parts of the face such as periorbital area and above zygoma (Figure 1, 2). Other lesions were seen on the hands (five patients), chest area (three), back (two),

Table 1. Demographic features of non-melanoma skin cancer
patients


waist (two), legs, abdomen, arms and base of the mouth.

The most common histopathologic type of BCC was nodular, followed by mixed and superficially spreading types. Typing could not be done in 16 patients with SCC, and 15 were classified as well-differentiated (Table 3).

\section{Discussion}

Basal cell cancer is typically seen in elderly patients, in those with light skin texture, light colored hair and eye, and in skin regions exposed to sunlight (4). It is particularly common in the face area (forehead, nose, malar area, upper lips, eyelids, etc.), and rarely metastasizes (6). About $10 \%$ to $15 \%$ of SCCs occur on the body, however, despite intense exposure to sunlight, they are rarely seen in hands and dorsal parts of the arms. SCC also develops frequently from the sun-exposed areas of the skin. However, some forms can originate from various parts

\begin{tabular}{|c|c|c|c|}
\hline & & $\mathrm{n}$ & $\%$ \\
\hline \multirow{2}{*}{ Head and neck localize NMSC } & Yes & 106 & 88.3 \\
\hline & No & 14 & 11.7 \\
\hline
\end{tabular}

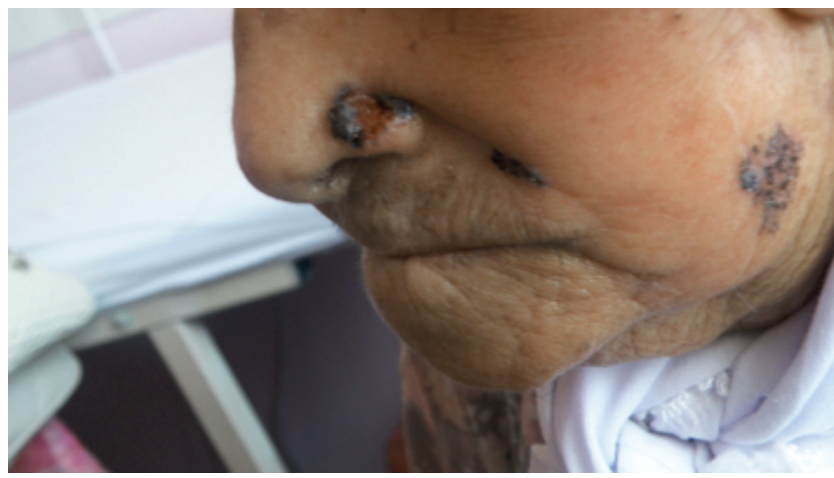

Figure 1. Multiple pigmente and ulsere basal cell carcinoma at the face

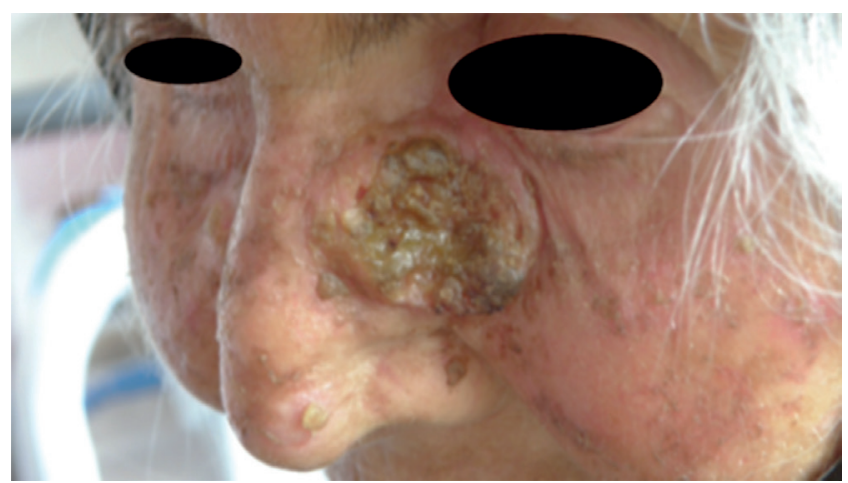

Figure 2. A giant nodular, basal cell carcinoma near to eye and multipl actinic keratoses of the skin depending on chronic trauma, burn scars and genetic disorders (7).

Milas county, the place where this study was conducted, is located in the southern Aegean region, and is one of the towns receiving heavy sunlight. Its population is approximately 100.000 and the most common occupations in this region involve tourism and agriculture, both performed under direct sunlight. In this article, for purpose of contributing to the literature, we report cancer rate and cancer location characteristics in patients who were admitted to the dermatology department at Milas State Hospital and histopathologically diagnosed with NMSC and underwent surgery between 2011 and 2014.

In a study conducted in our country, the average age of 576 patients with BCC was 55.2 years, and it was considered to be similar with that in the tropical regions (8). Similar to other studies in our country, the average age was found to be 65 in our study $(3,8,9)$. Our cases peaked at seventh decade. Although age at admission was consistent with the literature in our country, peak age was seventh decade, similar to that in countries such as Greece, Spain and Italy (10-12). Despite most of the people living in this region have light colored skin and eye, advanced peak age can be attributed to healthy diet like in European countries (13).

Although male dominance in NMSC is reported more often in the literature, there is no any difference in gender in Italian and Australian patients $(14,15)$. Male/female

\begin{tabular}{|c|c|c|c|}
\hline \multirow{2}{*}{ Tumor type } & $\mathrm{BCC}$ & 84 & 70.0 \\
\hline & SCC & 36 & 30.0 \\
\hline \multirow{14}{*}{$\begin{array}{l}\text { Histopathologic } \\
\text { type }\end{array}$} & BCC infiltrative & 3 & 2.5 \\
\hline & BCC keratotic & 3 & 2.5 \\
\hline & BCC morpheic & 1 & 0.8 \\
\hline & BCC nodular & 57 & 47.5 \\
\hline & $\begin{array}{l}\text { BCC mix (nodular, infiltrative, } \\
\text { micronodular) }\end{array}$ & 8 & 6.6 \\
\hline & $\begin{array}{l}\text { BCC nodular + SCC well } \\
\text { differentiated }\end{array}$ & 1 & 0.8 \\
\hline & $\begin{array}{l}\text { BCC nodular and superficially } \\
\text { spreading }\end{array}$ & 3 & 2.5 \\
\hline & BCC superficially spreading & 8 & 6.7 \\
\hline & SCC & 15 & 12.5 \\
\hline & SCC acantholitic & 1 & 0.8 \\
\hline & SCC in situ & 2 & 1.7 \\
\hline & SCC well differentiated & 15 & 12.5 \\
\hline & SCC microinvazive & 2 & 1.7 \\
\hline & SCC moderate differentiated & 1 & 0.8 \\
\hline
\end{tabular}


ratio was assessed as one in our study and this could prove the effect of sun rather than gender under the condition of equal exposure.

Annual statistical information about skin cancers is not reliable in our country. In our study, BCC incidence among patients with NMSC was $70 \%(n=84)$, which was consistent with the incidence in white Caucasians. SCC is the second most common skin cancer among white Caucasians, and constitutes $15 \%$ to $25 \%$ of all skin cancers $(3,8,9)$. In our study, SCC covered $30 \%$ of the cases $(n=36)$.

Exposure to sunlight is the most common factor emphasized among the etiologic factors in skin cancers. Especially depending on the occupation, exposure to sunlight shows an increase. Farmers, sailors and fishermen are the occupational groups that bear the most risk of excessive sun exposure (16). Since our hospital is in Aegean Region, a geographical area of high ultraviolet all around the year, it is estimated that the incidence of skin cancers would be high. A national study on this topic would establish the regional differences.

Various sources report that the most common area of the face that involves BCC is the nasal region, with a frequency of $25-30 \%$. SCC, however, more likely involves the scalp and superior auricular area $(6,7,17)$. As in other studies, the nasal unit is the most common site for skin cancers in our study. Fourty lesions were nasal tumors and 32 were buccal and periorbital tumors. In the literature, there are reports that nasal unit was followed by forehead and buccal units. In eleven patients, skin lesions were located in the auricular region. Kwa et al. (18) reported that SCC of the ear was more likely located on sun-exposed superior portion of the helix.

It was observed that all the patients included in this study were farmers. Smoking and/or alcohol use was present in $30(25 \%)$ of our patients. The presence of history of smoking in about half of the cases with lip lesion can be considered as significant. Smoking and alcohol consumption are rather crucial among the etiologic factors of lip cancer $(19,20)$.

Recurrence rates in patients who had insufficient resection and tumor in surgical margins were reported to be between $12 \%$ and $13 \%$ in various studies (21-24). According to the medical history obtained from 120 patients, 15 had a previous lesion on a distinct area of the face that was treated for skin cancer. Lesion recurrence was observed during the follow-up of 15 patients. It has been reported in the literature that risk of developing a second lesion within the first two to five years after the first lesion can be as high as $50 \%$. The average followup time in our patients was 16 months and the longest follow-up was 42 months. Rowe et al. (25) and Silverman et al. (26) reported a recurrence rate of 3-5\% for small lesions and 9-10\% for large lesions during five-year followup after excisional surgery of BCCs. Pascal et al. (27) reported that two years of follow-up in average is required to observe recurrence in positive surgical margins in BCCs. In SCCs, however, $70-85 \%$ of the recurrences are seen within the first two years $(25,28)$. The recurrence rate of approximately $10 \%$ in our study can be attributed to deficiency in surgical intervention.

Male dominance has been reported in different regions of our country (28-30). In their ten-year study that was performed in a region having the same climate as Milas, have reported that the prevalence of NMSC among women was rapidly increasing. In studies where NMSC was seen only in the ear cap, the rate of males was higher than females (16/1) (31). This is the first study of women and men equality in our country in the literature we could reach.

\section{Conclusion}

It was determined that the frequency of recurrence and the frequency of the cases detected in a secondary care institution were found to be higher during the threeyear follow-up. We assume that increased frequency of skin cancers is an important health problem for this region and that the incidence will increase if preventive measures are not taken.

\section{Ethics}

Ethics Committee Approval: Retrospective study. Informed Consent: It was taken.

Peer-review: Externally and internally peer-reviewed.

\section{Authorship Contributions}

Surgical and Medical Practices: Ş.A., K.B. Concept: Ş.A., K.B. Design: Ş.A., K.B. Data Collection or Processing: Ş.A., K.B. Analysis or Interpretation: Ş.A., K.B. Literature Search: Ş.A., K.B. Writing: Ş.A., K.B.

Conflict of Interest: No conflict of interest was declared by the authors.

Financial Disclosure: The authors declared that this study received no financial support.

\section{References}

1. Leiter $U$, Garbe C. Epidemiology of melanoma and nonmelanoma skin cancer-the role of sunlight. Adv Exp Med Biol 2008;624:89-103.

2. Soyer HP, Rigel DS, Wurm EMT. Actinic keratosis, basal cell carcinoma and squamous cell carcinoma. in Dermatology. In: Bolognia JL, Jorizzo JL, Schaffer JV, editors. Elsevier Saunders, Beijing, China; 2012. p. 1773-93.

3. Demirseren DD, Ceran C, Aksam B, Demirseren ME, Metin A. Basal cell carcinoma of the head and neck region: a 
retrospective analysis of completelyexcised 331 cases. J Skin Cancer 2014;2014:858636.

4. Diepgen TL, Mahler $\mathrm{V}$. The epidemiology of skin cancer. Br J Dermatol 2002;146(Suppl 61):1-6.

5. Weinstock MA. Epidemiology of nonmelanoma skin cancer: clinical issues, definitions and classification. J Invest Dermatol 1994;102:4-5.

6. Gallagher RP, Hill GB, Bajdik CD, et al. Sunlight exposure, pigmentary factors, and risk of nonmelanocytic skin cancer. I. Basal cell carcinoma. Arch Dermatol. 1995;131:157-63.

7. Gallagher RP, Hill GB, Bajdik CD, et al. Sunlight exposure, pigmentary factors, and risk of nonmelanocytic skin cancer. II. Squamous cell carcinoma. Arch Dermatol 1995;131:164-9.

8. Tirelioğlu S, Özgenel GŞ, Filiz G, et al. Retrospective Analysis of 576 Patients with Basal Cell carcinoma. Turk J Plast Surg 2004:12;18-20.

9. Ceylan C, Oztürk G, Alper S. Non-melanoma skin cancers between the years of 1990 and 1999 in Izmir, Turkey: demographic and clinicopathological characteristics. J Dermatol 2003;30:123-31.

10. Seretis K, Thomaidis V, Karpouzis A, Tamiolakis D, Tsamis I. Epidemiology of surgical treatment of nonmelanoma skin cancer of the head and neck in Greece. Dermatol Surg 2010;36:15-22.

11. Revenga Arranz F, Paricio Rubio JF, Mar Vazquez Salvado M, del Villar Sordo V. Descriptive epidemiology of basal cell carcinoma and cutaneous squamous cell carcinoma in Soria (north-eastern Spain) 1998-2000: a hospital-based survey. J Eur Acad Dermatol Venerol 2004;18:137-41.

12. Boi S, Cristofolini M, Micciolo R, Polla E, Dalla Palma P. Epidemiology of skin tumors: data from the cutaneous cancer registry in Trentino, Italy. J Cutan Med Surg 2003;7:300-5.

13. Mathers CD, Murray CJ, Salomon JA, et al. Healthy life expectancy: comparison of OECD countries in 2001. Aust N Z J Public Health 2003;27:5-11.

14. Czarnecki D, Collins N, Meehan C, O'Brien T, Leahy S, Nash C. Basal cell carcinoma in temperate and tropical Australia. Int J Cancer 1992;50:874-5.

15. Betti R, Inselvini E, Carducci M, Crosti C. Age and site prevalence of histologic subtypes of basal cell carcinomas. Int J Dermatol 1995;34:174-6.

16. Almahroos M, Kurban AK. Ultraviolet carcinogenesis in nonmelanoma skin cancer. Part I: incidence rates in relation to geographic locations and in migrant populations. Skinmed 2004;3:29-35.

17. Gloster HM Jr, Neal K. Skin cancer in skin of color. J Am Acad Dermatol 2006;55:741-60.
18. Kwa RE, Campana K, Moy RL. Biology of cutaneous squamous cell carcinoma. J Am Acad Dermatol 1992;26:1-26.

19. Rowe DE, Carroll RJ, Day CL Jr. Prognostic factors for local recurrence, metastasis, and survival rates in squamous cell carcinoma of the skin, ear, and lip. Implications for treatment modality selection. J Am Acad Dermatol 1992;26:976-90.

20. Johnson TM, Rowe DE, Nelson BR, Swanson NA. Squamous cell carcinoma of the skin (excluding lip and oral mucosa). J Am Acad Dermatol 1992;26:467-84.

21. Telfer NR, Colver GB, Bowers PW. Guidelines for the management of basal cell carcinoma. British Association of Dermatologists. Br J Dermatol 1999;141:415-23.

22. Agirgol S, Mansur AT, Bozkurt K, Azakli HN, Babacan A, Dikmen A. Giant Cornu Cutaneum Superimposed on Basal Cell Carcinoma. West Indian Med J 2015;64:438-40.

23. Thomas DJ, King AR, Peat BG. Excision margins for nonmelanotic skin cancer. Plast Reconstr Surg 2003;112:5763.

24. Bisson MA, Dunkin CS, Suvarna SK, Griffiths RW. Do plastic surgeons resect basal cell carcinomas too widely? A prospective study comparing surgical and histological margins. Br J Plast Surg 2002;55:293-7.

25. Rowe DE, Carroll RJ, Day CL Jr. Long-term recurrence rates in previously untreated (primary) basal cell carcinoma: implications for patient follow-up. J Dermatol Surg Oncol 1989;15:315-28.

26. Silverman MK, Kopf AW, Bart RS, Grin CM, Levenstein MS. Recurrence rates of treated basal cell carcinomas. Part 3: Surgical excision. J Dermatol Surg Oncol 1992;18:471-6.

27. Pascal RR, Hobby LW, Lattes R, Crikelair GF. Prognosis of "incompletely excised" versus "completely excised" basal cell carcinoma. Plast Reconstr Surg 1968;41:328-32.

28. de Visscher JG, Gooris PJ, Vermey A, Roodenburg JL. Surgical margins for resection of squamous cell carcinoma of the lower lip. Int J Oral Maxillofac Surg 2002;31:154-7.

29. İnözü E, Eryılmaz AT, Arpacı E, Durgun M, Horoz U, Tellioğlu AT. Bazal Hücreli Karsinom: 5 Yıllık Deneyim. Ortadoğu Tıp Dergisi 2012;4:57-60.

30. Şenel E, Karabulut YY, Karabulut HH, ve ark. Çankırı yöresinde deri biyopsilerinin değerlendirilmesi: İki yıllık retrospektif bir değerlendirme. Turk J Dermatol 2014;3:151-3.

31. Çiloğlu S, Duran A, Yiğit A, Büyükdoğan $H$, Keskin E. Kulak Kepçesi Yerleşimli Melanom Dışı Deri Kanserleri: 51 Olgunun Geriye Dönük Analizi. Turk J Dermatol 2015;9:177-80. 